\title{
Chemical Thermodynamic Processes at Metal-Mold Interface
}

\author{
Zoran Janjušević, Zvonko Gulišija, Marija Mihailović, Aleksandra Patarić, \\ Miroslav Sokić, Branislav Marković and Vladislav Matković \\ Institute for Technology of Nuclear and Other Mineral Raw Materials, Franchet d'Esperey 86, 1100 Belgrade, Serbia
}

\begin{abstract}
At the contact surface between the liquid metal and the mold wall a number of chemical and thermodynamical reactions were taken. The products of those reactions are spread out on both the sides, i.e., in the solidified metal or into the mold wall. The processes which took place in the casting mold - here made from sand mix, during the pouring of liquid metal, solidification and cooling down to room temperature, are pretty complex.

The thermodynamic reactions at the contact surface of liquid metal/sand mold in the process of castings forming are discussed in this paper. Experiments were performed in molds made by $\mathrm{CO}_{2}$ sand casting process. As a pouring metal we used steels from an ordinary production program of a steel foundry, exactly it was the steel GS 50CrMo4, assigned by DIN.

Some results obtained in our investigations during studying those processes are shown here. [doi:10.2320/matertrans.M2013190]
\end{abstract}

(Received May 23, 2013; Accepted July 26, 2013; Published September 25, 2013)

Keywords: casting process, metal, mold, chemical processes, thermodynamic processes

\section{Introduction}

The process of castings forming is investigated mostly from chemical and/or thermodynamical point of view in the liquid metal system during solidification from the pouring to the room temperature. In this phase of casting formation a lot of chemical reactions may take place, while heat exchange between the liquid metal and the mold is very intensive. The casting formation is followed by many processes which have significant influence on the casting quality.

In consideration the interactions on the surface between a mold and a liquid metal, the following parameters should be included: primary metal $(\mathrm{M})$, alloying elements $\left(\mathrm{M}_{1}\right.$, $\mathrm{M}_{2} \ldots \mathrm{M}_{\mathrm{i}}$ ), oxygen $(\mathrm{O})$, smelting oxides of mold's material (RO) and temperature. Three types of chemical reactions can occur between the components in process on the mold surface: ${ }^{1)}$

$$
\begin{aligned}
& \mathrm{M}_{1}, \mathrm{M}_{\mathrm{i}}+1 / 2 \mathrm{O}_{2}=\mathrm{MO}, \mathrm{M}_{\mathrm{i}} \mathrm{O} \\
& \mathrm{M}_{1}, \mathrm{M}_{\mathrm{i}}+\mathrm{RO}=\mathrm{M}_{1} \mathrm{O}, \mathrm{M}_{\mathrm{i}} \mathrm{O}+\mathrm{R} \\
& \mathrm{M}_{1} \mathrm{O}, \mathrm{M}_{\mathrm{i}} \mathrm{O}+\mathrm{RO}=\mathrm{M}_{1} \mathrm{O} \mathrm{RO}, \mathrm{M}_{\mathrm{i}} \mathrm{O} \mathrm{RO}
\end{aligned}
$$

The equilibrium of these reactions is determined by the occurrence at the liquid metal/mold interface.

The chemical reactions are to a great extent determined by thermodynamic laws. The heat of oxide formation gives an approximate value of metal $\left(\mathrm{M}_{1,2,3}\right)$ affinity to oxygen $(\mathrm{O})$. It is known that the oxide formation is influenced by the metal concentration and the changes of oxides thermodynamic potential, indicating the possibility of reaction ongoing, the direction of reaction, stability of formed components, etc. The more negative standard Gibbs energy of oxide formation, the greater the affinity of metal oxide formation and the formed oxide is more stable.

The change of standard Gibbs energy ${ }^{2-4)}$ of a particular material is determined by the following equation:

$$
\Delta G_{\mathrm{T}}^{o}=\Delta H_{\mathrm{T}}^{o}-T \Delta S_{\mathrm{T}}^{o}
$$

where: $\Delta H$ and $\Delta S$ are the changes of standard enthalpy and entropy, respectively, during the formation of a compound at temperature $T$.
For the small differences between the heats of oxides formation, the standard Gibbs energy for all the components should be used. So, even if a small quantity of a constituent from the sand mold mixture is present, its oxide will appear at the surface layer when this constituent's affinity to oxygen is high enough.

Metal oxidation (eqs. (5), (6)) in the mold occurs during the liquid metal and oxygen contact, but also after melt solidification. ${ }^{2)}$ The composition of gas-phase in contact with solidified metal, depending on the mold mixture composition, can vary in a wide range in terms of $\mathrm{CO}, \mathrm{CO}_{2}, \mathrm{H}_{2}, \mathrm{O}_{2}$ contents, what determines its oxidation potential.

Some examples of oxidation reactions:

$$
\begin{aligned}
& 2 \mathrm{Fe}_{(\mathrm{s})(\mathrm{l})}+\mathrm{O}_{2(\mathrm{~g})}=2 \mathrm{FeO}_{(\mathrm{l})(\mathrm{s})} \\
& 2 \mathrm{Mn}_{(\mathrm{s})}+\mathrm{O}_{2(\mathrm{~g})}=2 \mathrm{MnO}_{(\mathrm{l})(\mathrm{s})}
\end{aligned}
$$

Carbon (IV)-oxide can be produced and consumed according to reactions $(7,8,9)$.

Oxidation of $\mathrm{CO}$ to $\mathrm{CO}_{2}$ :

$$
\mathrm{CO}_{(\mathrm{g})}+1 / 2 \mathrm{O}_{2}=\mathrm{CO}_{2(\mathrm{~g})}
$$

Gasification of carbon:

$$
\mathrm{C}_{(\mathrm{s})}+\mathrm{CO}_{2(\mathrm{~g})}=2 \mathrm{CO}_{(\mathrm{g})}
$$

The possible reaction of oxidation:

$$
\mathrm{Fe}_{(\mathrm{s})(\mathrm{l})}+\mathrm{CO}_{2(\mathrm{~g})}=\mathrm{FeO}_{(\mathrm{l})(\mathrm{s})}+\mathrm{CO}_{(\mathrm{g})}
$$

At the same time, the hydrogen content can arise in the gas phase up to $60 \%$ or more. ${ }^{3)}$ It reacts forming other gasses. Hydrogen can be produced and consumed during processes shown in reactions (eqs. (10)-(14)).

Reaction of $\mathrm{CO}_{2}$ with hydrogen

$$
\mathrm{CO}_{2(\mathrm{~g})}+\mathrm{H}_{2(\mathrm{~g})}=\mathrm{CO}_{(\mathrm{g})}+\mathrm{H}_{2} \mathrm{O}_{(\mathrm{g})}
$$

Reaction of carbon with steam:

$$
\begin{aligned}
& \mathrm{C}_{(\mathrm{s})}+\mathrm{H}_{2} \mathrm{O}_{(\mathrm{g})}=\mathrm{CO}_{(\mathrm{g})}+\mathrm{H}_{2(\mathrm{~g})} \\
& \mathrm{C}_{(\mathrm{s})}+2 \mathrm{H}_{2} \mathrm{O}_{(\mathrm{g})}=\mathrm{CO}_{2(\mathrm{~g})}+2 \mathrm{H}_{2(\mathrm{~g})}
\end{aligned}
$$

Disassociation of hydrocarbons 


$$
\mathrm{CH}_{4(\mathrm{~g})}=\mathrm{C}_{(\mathrm{s})}+2 \mathrm{H}_{2(\mathrm{~g})}
$$

The possible reaction of oxidation:

$$
\mathrm{Fe}_{(\mathrm{s})(\mathrm{I})}+\mathrm{H}_{2} \mathrm{O}_{(\mathrm{g})}=\mathrm{FeO}_{(\mathrm{l})(\mathrm{s})}+\mathrm{H}_{2(\mathrm{~g})}
$$

Matveev and coauthors ${ }^{5)}$ provided the thermodynamical analyses of chemical reactions probability between metals, as well as between different metals with orthosilicates in the temperature interval $1000-1600 \mathrm{~K}$. They have started from the wide known equation:

$$
\mathrm{Me}^{\prime}+\mathrm{Me}^{\prime \prime} \mathrm{SiO}_{3}=\mathrm{Me}^{\prime} \mathrm{SiO}_{3}+\mathrm{Me}^{\prime \prime}
$$

They found that the heat of formation at $1000 \mathrm{~K}$ is on the level of $-16 \mathrm{~kJ} / \mathrm{mol}$ for sillimanite, but at $1600 \mathrm{~K}$, the heat of formation is on the level of $-17,6 \mathrm{~kJ} / \mathrm{mol}$. The thermodynamic analysis has also shown that aluminum easily reacts with $\mathrm{FeO}$ at $1000 \mathrm{~K}(-638 \mathrm{~kJ} / \mathrm{mol})$ and may also react with silicates of the following metals: $\mathrm{Ni}, \mathrm{Co}, \mathrm{Fe}, \mathrm{Mn}, \mathrm{Pb}, \mathrm{Li}$ and $\mathrm{Na}$. Since these silicates are in the liquid state at $1770 \mathrm{~K}$, the additional reactions with free $\mathrm{SiO}_{2}$ are possible, as well.

A structural model for a binary silicate systems including $\mathrm{MnO}-\mathrm{SiO}_{2}$ and $\mathrm{CaO}-\mathrm{SiO}_{2}$, as well as thermodynamics of $\mathrm{Fe}_{3} \mathrm{O}_{4}-\mathrm{Mn}_{3} \mathrm{O}_{4}$ spinels are presented in the work of Pelton et al. ${ }^{6,7)}$ A. Semykina and a few other authors worked on the oxidizing kinetics of the liquid $\mathrm{FeO}-\mathrm{MnO}-\mathrm{CaO}-\mathrm{SiO}_{2}$ slags. ${ }^{8-10)}$

\section{Experimental Procedure}

For investigation of chemical and thermodynamical changes at the contact surface of liquid metal/sand mold, the steel 50CrMo4 (according to DIN standard) from an ordinary production program of a steel foundry was used.

Experimental casts were cylindrical in shape, with diameter of $0.038 \mathrm{~m}$ and length of $0.060 \mathrm{~m}$. Casting temperature was in the range of $1853-1873 \mathrm{~K}$, with initial temperature of the mold and its external surface equal to the environment temperature $(\sim 20 \mathrm{~K})$.

The experiments were conducted in molds made according to $\mathrm{CO}_{2}$ procedure. Mold mixture consisted of about $90 \%$ quartz sand, $6 \%$ water-glass, $0.1 \%$ sodium (I)-sulfate and remainder up to $100 \%$ of active components.

Oxides of titanium and magnesium, $\mathrm{TiO}_{2}$ and $\mathrm{MgO}$, were used as active components which transfer binary system $\mathrm{Na}_{2} \mathrm{O}-\mathrm{SiO}_{2}$, into ternary system $\mathrm{Na}_{2} \mathrm{O} \quad \mathrm{SiO}_{2} \quad \mathrm{M}_{\mathrm{x}} \mathrm{O}_{\mathrm{y}}$ with higher viscosity and surface tension. We also used sulfates of aluminum, sodium and potassium, where sodium sulfate was constantly present component in the mold mixture and aluminum sulfate and aluminum-potassium sulfate were added as active components. Due to thermal effects in the mold during processes of casting, solidification and cooling down of a cast, these active components dissociate releasing gassy reaction products and steam from chemically bonded moisture, which additionally affects oxidation of metal fibrils and thereby formation of new compounds in contact zone of metal and mold.

\section{Results and Discussion}

Segment of the mold with visible changes in mold mixture

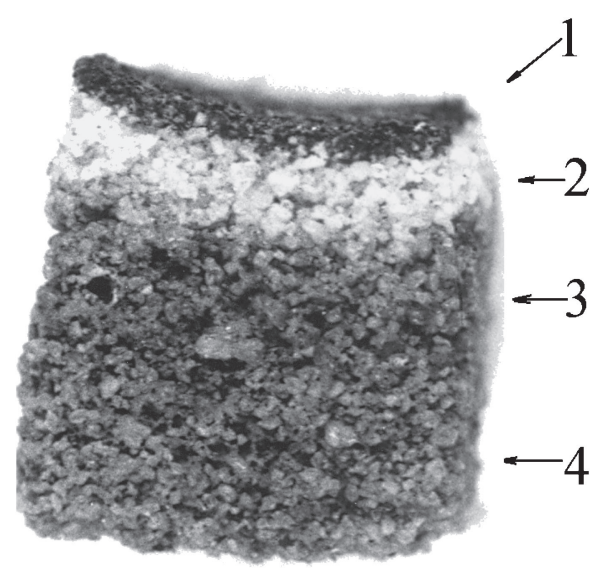

Fig. 1 Segment of the mold with visible zones.

Table 1 Width of newly-formed zones in the mold.

\begin{tabular}{ccc}
\hline \multicolumn{3}{c}{ Zone width, mm } \\
\hline $\mathrm{I}$ & $\mathrm{II}$ & $\mathrm{III}$ \\
\hline 1.639 & 3.172 & 5.728 \\
1.536 & 3.063 & 4.336 \\
1.382 & 2.972 & 4.329 \\
1.347 & 2.521 & 3.802 \\
1.369 & 3.685 & 5.384 \\
1.604 & 3.596 & 5.126 \\
1.373 & 3.290 & 5.025 \\
1.302 & 3.101 & 4.547 \\
1.090 & 3.081 & 4.902 \\
1.035 & 2.904 & 4.781 \\
1.090 & 2.988 & 5.034 \\
1.132 & 3.976 & 5.275 \\
1.289 & 3.727 & 5.066 \\
1.302 & 3.790 & 5.125 \\
1.226 & 3.784 & 5.112 \\
1.168 & 2.314 & 5.376 \\
1.313 & 3.511 & 5.079 \\
\hline
\end{tabular}

occurred due to its reaction with metal, as well as non-reacted part of the mold mixture are given in Fig. 1. ${ }^{11)}$ The corresponding changes, depending on temperature, occurred in the first three zones, while the fourth layer remained unchanged.

The measurements of the zones width are given in Table 1.

The first dark colored zone is a region of penetration of liquid metal into the mold pores. This zone is formed just after the liquid metal pouring into the mold cavity, and the penetration of liquid metal is pretty intensive into the pores of sand mold mix. In fact, this leads to intensive reaction through the entire interface, so the consequence will be the maximal speed of reaction layer formation. Since processes on metal-mold contact surface directly depend on the mold temperature, the penetration of liquid phase into the mold pores will be more intense with the increase of temperature. Consequently, the process of liquid phase chemical interaction will be shifted in the mold depth.

In the second, light colored zone, the change of $\alpha$-quartz into the $\beta$-quartz occurred. 


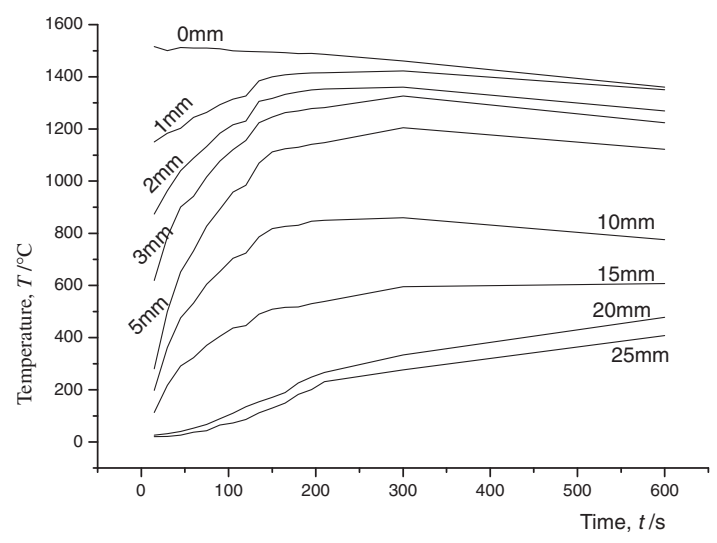

Fig. 2 Temperature-time dependence at the cross-section of the mold with the addition of $\mathrm{MgO}+\mathrm{TiO}_{2}+\mathrm{AlK}\left(\mathrm{SO}_{4}\right)_{2}$.

The third grey zone is the area of small changes.

The fourth zone is a layer of unchanged mold mixture with unchanged compounds and properties.

The temperature measuring at the cross-section of the mold with the addition of $\mathrm{MgO}+\mathrm{TiO}_{2}+\mathrm{AlK}\left(\mathrm{SO}_{4}\right)_{2}$ started from the contact surface $(0 \mathrm{~mm})$, and further at distances at $1,2,3$, $5,10,15,20$ and $25 \mathrm{~mm}$ from the contact surface to the core of mold. This measuring shows the temperature distribution into the mold depth with elapsed time, Fig. 2.

At those temperatures, the dehydration will took place, as well as the oxides and new minerals formation, ${ }^{12)}$ as could be seen from Fig. 3 .

The formation of new products, as a result of mutual activity at the contact surface liquid metal/sand mold mixture is determined by kinetics and temperatures distribution. The consequence of both, the oxidation of elements and the formation of silicates is determined by element's concentration and the change of thermodynamic potential of oxides and silicates formation, which give the reaction probability, reaction direction and the stability of formed product.

The more negative value of the Gibbs energy of a compound formation, the reaction product will be a new mineral, pretty stable one.

The rate of new products formation, either oxide or silicate type, is depending on the oxygen presence. The oxygen is present in the surrounding atmosphere, penetrated into sand mix pores, but also it may originate from another gas. The oxygen from chemical stable compounds would not have any remarkable influence on the formation of new oxides or silicates.

During the casting forming, in the period after pouring a mold, the temperatures fall rapidly. Even when the metal is crystallized, in the period when the metal is at solid state but still pretty hot, the intensive reactions also are possible. Both, oxides and/or silicates at the contact surface could be formed. Then, the potential reactions will be: ${ }^{1)}$

$$
\begin{aligned}
& \mathrm{Na}_{2} \mathrm{SO}_{4} \cdot 10 \mathrm{H}_{2} \mathrm{O} \\
& \rightarrow \mathrm{Na}_{2} \mathrm{O}+\mathrm{SO}_{2}+1 / 2 \mathrm{O}_{2}+10 \mathrm{H}_{2} \mathrm{O} \\
& \mathrm{Na}_{2} \mathrm{CO}_{3} \rightarrow \mathrm{Na}_{2} \mathrm{O}+\mathrm{CO}_{2} \\
& \mathrm{Na}_{2} \mathrm{O}+3 \mathrm{SiO}_{2} \rightarrow \mathrm{Na}_{2} \mathrm{Si}_{3} \mathrm{O}_{7} \\
& 2 \mathrm{AlK}\left(\mathrm{SO}_{4}\right)_{2} \cdot 12 \mathrm{H}_{2} \mathrm{O} \\
& \rightarrow \mathrm{Al}_{2} \mathrm{O}_{3}+\mathrm{K}_{2} \mathrm{O}+4 \mathrm{SO}_{2}+2 \mathrm{O}_{2}+12 \mathrm{H}_{2} \mathrm{O} \\
& \mathrm{K}_{2} \mathrm{O}+\mathrm{SiO}_{2} \rightarrow \mathrm{K}_{2} \mathrm{SiO}_{3} \\
& \mathrm{~K}_{2} \mathrm{O}+4 \mathrm{SiO}_{2} \rightarrow \mathrm{K}_{2} \mathrm{Si}_{4} \mathrm{O}_{9} \\
& 2 \mathrm{MgO}+\mathrm{SiO}_{2} \rightarrow 2 \mathrm{MgO} \cdot \mathrm{SiO}_{2} \\
& \mathrm{Na}_{2} \mathrm{O}+\mathrm{Al}_{2} \mathrm{O}_{3}+6 \mathrm{SiO}_{2} \rightarrow \mathrm{Na}_{2} \mathrm{O} \cdot \mathrm{Al}_{2} \mathrm{O}_{3} \cdot 6 \mathrm{SiO}_{2} \\
& 4 \mathrm{FeO} \rightarrow \mathrm{Fe}_{3} \mathrm{O}_{4}+\mathrm{Fe} \\
& 1 / 2 \mathrm{Fe}_{2} \mathrm{O}_{3}+\mathrm{SiO}_{2} \rightarrow \mathrm{FeO} \cdot \mathrm{SiO}_{2}+1 / 4 \mathrm{O}_{2} \\
& \mathrm{Fe}_{2} \mathrm{O}_{3}+\mathrm{SiO}_{2} \rightarrow 2 \mathrm{FeO} \cdot \mathrm{SiO}_{2}+1 / 2 \mathrm{O}_{2} \\
& \mathrm{FeO}+\mathrm{SiO}_{2} \rightarrow \mathrm{FeO} \cdot \mathrm{SiO}_{2} \\
& 2 \mathrm{FeO}+\mathrm{SiO}_{2} \rightarrow 2 \mathrm{FeO} \cdot \mathrm{SiO}_{2} \\
& 1 / 3 \mathrm{Fe}_{3} \mathrm{O}_{4}+\mathrm{SiO}_{2} \rightarrow \mathrm{FeO} \cdot \mathrm{SiO}_{2}+1 / 6 \mathrm{O}_{2} \\
& 2 / 3 \mathrm{Mn}_{3} \mathrm{O}_{4}+\mathrm{SiO}_{2} \rightarrow 2 \mathrm{MnO} \cdot \mathrm{SiO}_{2}+1 / 3 \mathrm{O}_{2} \\
& 1 / 4 \mathrm{Mn}_{2} \mathrm{O}_{3}+\mathrm{SiO}_{2} \rightarrow \mathrm{MnO} \cdot \mathrm{SiO}_{2}+1 / 4 \mathrm{O}_{2} \\
& \mathrm{Mn}_{2} \mathrm{O}_{3}+\mathrm{SiO}_{2} \rightarrow 2 \mathrm{MnO} \cdot \mathrm{SiO}_{2}+1 / 2 \mathrm{O}_{2} \\
& \mathrm{FeO}+\mathrm{TiO}_{2} \rightarrow \mathrm{FeO} \cdot \mathrm{TiO}_{2} \\
& \mathrm{CaO}+\mathrm{TiO}_{2}+\mathrm{SiO}_{2} \rightarrow \mathrm{CaO} \cdot \mathrm{TiO}_{2} \cdot \mathrm{SiO}_{2} \\
& \mathrm{TiO}_{2} \rightarrow \mathrm{TiO}+1 / 2 \mathrm{O}_{2}
\end{aligned}
$$

The equations of Gibbs energy as a function of temperature are calculated and are presented in eqs. (36)-(55) for every reaction (16)-(35):

(16): $\Delta G_{\mathrm{T}}=1327597+430,14 T \ln T+0,072 T^{2}-5,22 \times 10^{-5} T^{-1}-4621 T$

(17): $\Delta G_{\mathrm{T}}=318937+51,34 T \ln T-201 \times 10^{-3} T^{2}-8,8 \times 10^{-5} T^{-1}-374,5 T$

(18): $\Delta G_{\mathrm{T}}=-412109-63,9 T \ln T+58,11 \times 10^{-3} T^{2}+24,4 \times 10^{-5} T^{-1}-376 T$

(19): $\Delta G_{\mathrm{T}}=-5696675+730 T \ln T+91,94 \times 10^{-3} T^{2}+38,6 \times 10^{-5} T^{-1}-13518 T$

(20): $\Delta G_{\mathrm{T}}=-311605,4-91,07 T \ln T+5,96 \times 10^{-3} T^{2}+5,78 \times 10^{-5} T^{-1}-604,3 T$

(21): $\Delta G_{\mathrm{T}}=-510407,4-181,8 T \ln T+234,5 \times 10^{-3} T^{2}+111,4 \times 10^{-5} T^{-1}+1077 T$

(22): $\Delta G_{\mathrm{T}}=-186513,5+19,24 T \ln T+11,79 \times 10^{-3} T^{2}+6,64 \times 10^{-5} T^{-1}-121 T$

(23): $\Delta G_{\mathrm{T}}=-693337,2-296,7 T \ln T-24,6 \times 10^{-3} T^{2}-22,7 \times 10^{-5} T^{-1}+1925,7 T$

(24): $\Delta G_{\mathrm{T}}=49963,3-26,7 T \ln T+39,4 \times 10^{-3} T^{2}+14,56 \times 10^{-5} T^{-1}+174,7 T$

(25): $\Delta G_{\mathrm{T}}=78942,35+25,23 T \ln T-26,5 \times 10^{-3} T^{2}+1,21 \times 10^{-5} T^{-1}-210,6 T$

(26): $\Delta G_{\mathrm{T}}=200173,5+24 T \ln T-36,7 \times 10^{-3} T^{2}+11 \times 10^{-5} T^{-1}-256,7 T$

(27): $\Delta G_{\mathrm{T}}=-69254,43+9,95 T \ln T-21,2 \times 10^{-3} T^{2}-4,5 \times 10^{-5} T^{-1}-51,04 T$ 

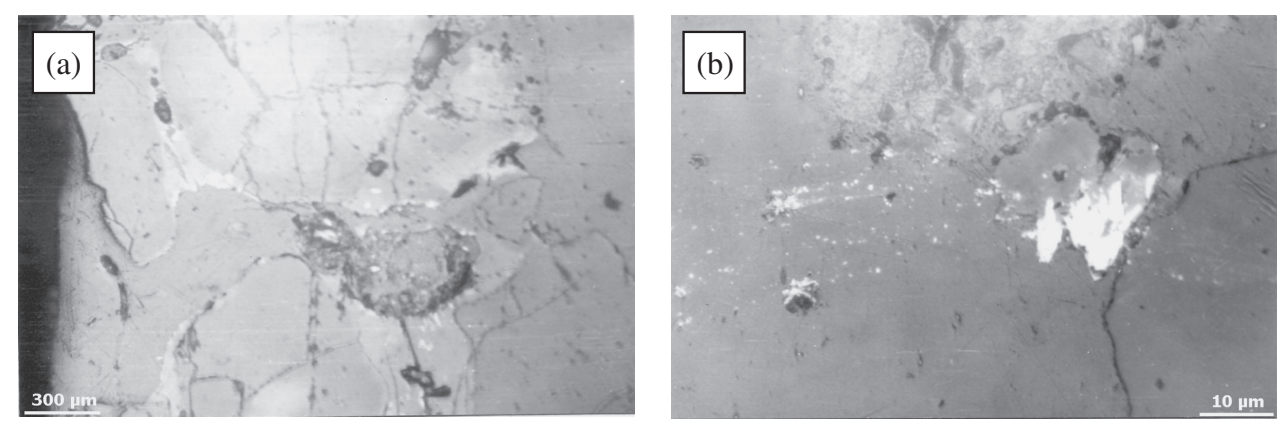

Fig. 3 Mineralogical identification of newly-formed minerals at the metal/-mold interface; (a) Fayalite and magnetite between the quartz grains; aluminosilicate. (b) Magnetite affected by martitization process; eutectic intergrowth of fayalite and quartz.
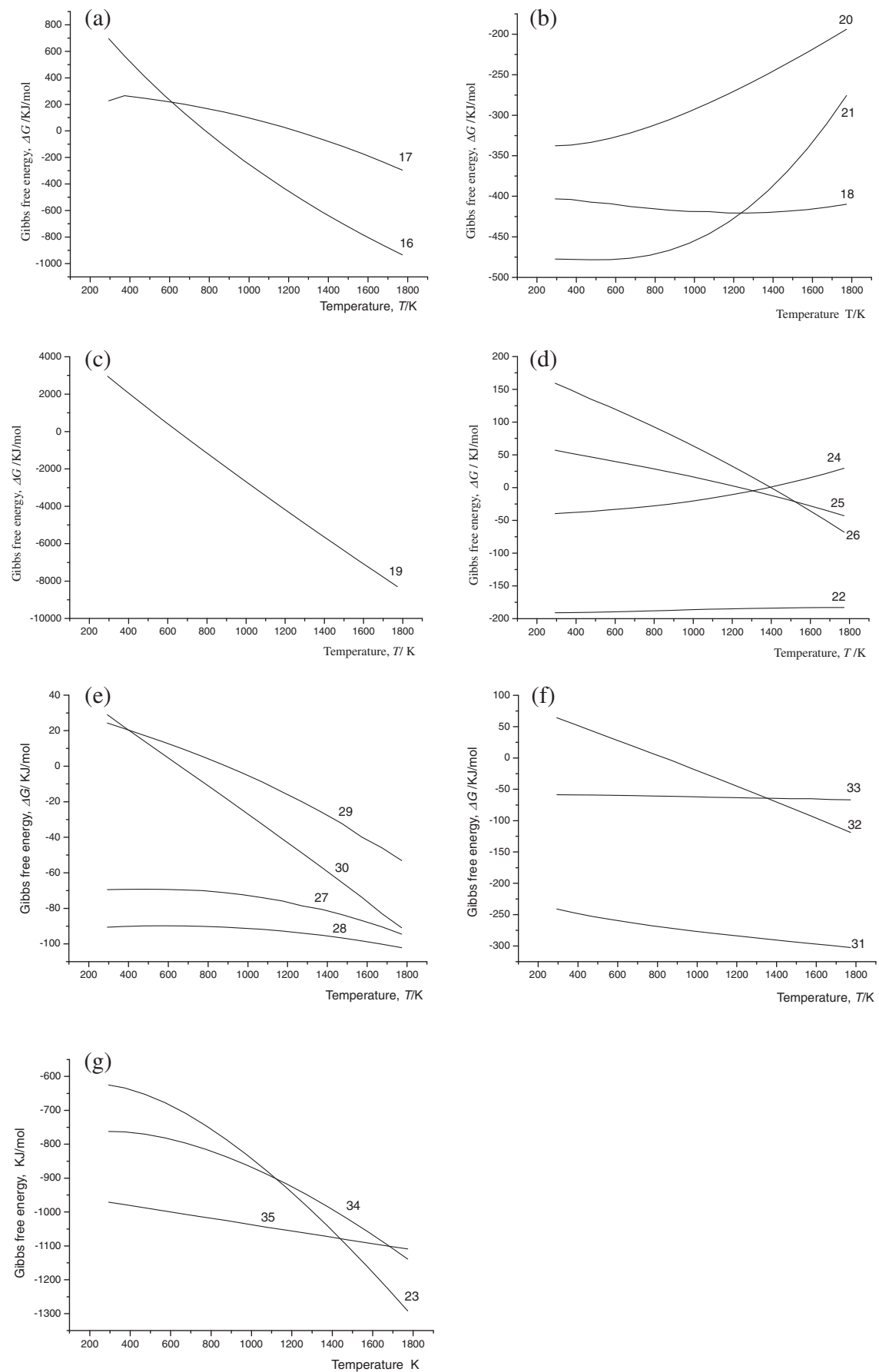

Fig. 4 The Gibbs free energy-temperature correlation for the chemical reactions (16)-(35); (a) for chemical reactions (16) and (17) (b) for chemical reactions (18), (20), (21) (c) for chemical reaction (19) (d) for chemical reactions (22), (24), (25), (26) (e) for chemical reactions (27), (28), (29), (30) (f) for chemical reactions (31), (32), (33) (g) for chemical reactions (23), (34), (35). 


$$
\begin{aligned}
& \text { (28): } \Delta G_{\mathrm{T}}=-92290+1,65 T \ln T-9,7 \times 10^{-3} T^{2}+5,84 \times 10^{-5} T^{-1}-0,7 T \\
& \text { (29): } \Delta G_{\mathrm{T}}=36890+12,43 T \ln T-20,35 \times 10^{-3} T^{2}-2,8 \times 10^{-5} T^{-1}-107,7 T \\
& \text { (30): } \Delta G_{\mathrm{T}}=55804,12+12,33 T \ln T-9,2 \times 10^{-3} T^{2}+0,77 \times 10^{-5} T^{-1}-159 T \\
& \text { (31): } \Delta G_{\mathrm{T}}=-206344+47,11 T \ln T-14 \times 10^{-3} T^{2}+6,7 \times 10^{-5} T^{-1}-381,75 T \\
& \text { (32): } \Delta G_{\mathrm{T}}=101454+10,7 T \ln T-11,4 \times 10^{-3} T^{2}-2,6 \times 10^{-5} T^{-1}-184 T \\
& \text { (33): } \Delta G_{\mathrm{T}}=-60168-8,15 T \ln T+3,75 \times 10^{-3} T^{2}+0,93 \times 10^{-5} T^{-1}+51 T \\
& \text { (34): } \Delta G_{\mathrm{T}}=-816834-167,1 T \ln T-45,5 \times 10^{-3} T^{2}+32 \times 10^{-5} T^{-1}+1149 T \\
& \text { (35): } \Delta G_{\mathrm{T}}=-946310-10 T \ln T+6,6 \times 10^{-3} T^{2}-1,23 \times 10^{-5} T^{-1}-30,3 T
\end{aligned}
$$

The eqs. (36)-(55) are an analytical expression of the dependence $\Delta G=f(T)$, and the cumulative graph is shown in Fig. 4.

\section{Conclusions}

(1) The composition of reaction melt is complex, based on silicon, iron, manganese and potassium. It is mainly consisted of glassy phase with the occurrence of fayalite, wustite, spinel and a smaller share of other minerals.

(2) Reactions (16), (18), (20), (21), (22), (23), (24), (27), (28), (31), (33), (34) and (35) have negative values of Gibbs energy in related temperature interval, so they are thermodynamically possible and they will take place.

(3) Reaction (19) has the negative value of Gibbs energy at temperature of $778 \mathrm{~K}$, reaction (24) at $1216 \mathrm{~K}$, reaction (25) at $1200 \mathrm{~K}$, reaction $(26)$ at $1372 \mathrm{~K}$, reaction (29) at $873 \mathrm{~K}$, reaction (30) at $643 \mathrm{~K}$ and reaction (32) at $823 \mathrm{~K}$. These facts show that the reactions are possible at temperatures higher than listed, while those reactions will be impossible at lower temperatures. The lowest temperature values at which the reactions are possible can be determined by graphic extrapolation.

(4) The processes rate depends on kinetic conditions and it is the subject of other investigations, since the thermodynamics does not take it into account.

\section{Acknowledgement}

The authors wish to acknowledge the financial support from the Ministry of Education and Science of the Republic of Serbia, grants 34002 and 34023.

\section{REFERENCES}

1) Z. Janjušević: Contact Surface Metal-Mould, (Fondation Andrejević, Belgrade, Serbia, 2008) pp. 46-75.

2) A. N. Tsibrik: Fiziko-Khimicheskie Protsessy v Kontaktnoi Zone MetalForma, (Naukova dumka, Kiev, 1977) pp. 22-34.

3) S. Đorđević: Physical Chemistry, (Faculty of Technology and Metallurgy, Belgrade, 1993) pp. 143-148.

4) D. Malić: Thermodynamics and Thermo-Technics, (Građevinska knjiga, Belgrade, 1976) pp. 48-54.

5) G. M. Matveev: Fizika i Hemia Obrabotka Materialov 1 (1976) 36-82.

6) A. D. Pelton, H. Schmalzried and J. Sticher: Ber. Bunsenges. Phys. Chem. 83 (1979) 241-252.

7) A. Romero-Serrano and A. D. Pelton: Metall. Mater. Trans. B 26 (1995) 305-315.

8) A. Semykina, V. Shatokha, M. Iwase and S. Seetharaman: Metall. Mater. Trans. B 41 (2010) 1230-1239.

9) A. Semykina, J. Nakano, S. Sridhar, V. Shatokha and S. Seetharaman: Metall. Mater. Trans. B 42 (2011) 471-476.

10) A. Semykina, J. Nakano, S. Sridhar, V. Shatokha and S. Seetharaman: Metall. Mater. Trans. B 41 (2010) 940-945.

11) Z. Janjušević, Z. Gulišija, S. Radosavljević and Z. Aćimović: Mater. Lett. 45 (2000) 235-240.

12) P. Ramdohr: The Ore Minerals and Their Intergrowths, (Pergamon Press, Oxford, 1988) p. 1120. 